\title{
GAMBARAN PENYESUAIAN DIRI MAHASISWA BARU
}

Iflah*

\author{
Winda Dwi Listyasari**
}

*Fakultas Ilmu Pendidikan, Universitas Negeri Jakarta

**Fakultas Ilmu Pendidikan, Universitas Negeri Jakarta

DOI: https://doi.org/10.21009/JPPP.021.05

\section{Alamat Korespondensi:}

iflah.iflah@gmail.com

\begin{abstract}
This research aims to describe the self adjustment of 2012 new students of Psychology programs, as well as determine the factors affecting self adjustment on 2012 new students of Psychology Programs. This research conducted at the D campus of the Psychology Program, Universitas Negeri Jakarta. This research used sequential mixed methods which conducted in two phases, starting with quantitative phase and followed by qualitative phase. Based on the result of quantitative phase, three respondents were selected to join in qualitative phase. Qualitative data collected by using interview technique. The results showed that 49 respondents (96,07\%) include in the high category of self adjustment and 2 respondents (3,9\%) include in the low category. The factors affecting self adjustment of new students of Psychology Programs are: 1) peer environment, 2) the learning process, 3) willingness to learn, 4. activities or programs outside the academic activities.
\end{abstract}

\section{Keywords}

self adjustment, new students, mixed method

\section{Pendahuluan}

Bagi mahasiswa baru, memasuki perguruan tinggi sama seperti memulai jenjang baru layaknya siswa SD memasuki SMP dan siswa SMP memasuki SMA, setiap jenjang memiliki problematika tersendiri. Bagi remaja, sesuatu yang baru dapat menjadi hal yang menarik untuk dijalani, namun beberapa remaja merasa khawatir menghadapi kondisi yang baru.

Penyesuaian diri menjadi permasalahan umum yang ditemui pada mahasiswa baru. Hampir seluruhnya berkaitan dengan penyesuaian pada situasi baru di perguruan tinggi. Penyesuaian diri tidak mudah dilakukan pada remaja yang merupakan masa transisi antara masa anak dan masa dewasa yang mencakup perubahan biologis, kognitif, dan sosial-emosional dengan rentang usia antara 13-17 tahun (Hurlock, 1999).

Saat kita memasuki perguruan tinggi maka otomatis akan dihadapkan oleh berbagai macam perubahan dan saat itu pula mahasiswa dituntut untuk mampu menyesuaikan diri dengan lingkungan (Spencer \& Jeffrey, 1983). Ketika memasuki dunia perguruan tinggi berarti mahasiswa sudah diberikan suatu kemudahan dan kebebasan untuk menentukan sendiri hal-hal yang berkaitan dengan studinya.

Jika seseorang mampu menyesuaikan diri terhadap orang lain secara umum ataupun terhadap kelompoknya, dan memperlihatkan sikap serta tingkah laku yang menyenangkan berarti ia telah diterima oleh kelompok atau lingkungannya. Dengan kata lain, orang itu mampu menyesuaikan sendiri dengan baik terhadap lingkungannya (Santrock, 2002). Penyesuaian diri yang baik dapat terjadi jika seorang individu selalu dalam keadaan seimbang antara dirinya dengan lingkungannya, tidak ada lagi kebutuhan yang tidak terpenuhi, dan semua fungsi serta kebutuhan individu tersebut akan berjalan normal. Penyesuaian diri merupakan suatu proses sepanjang hidup, manusia harus mampu menemukan, mengatasi tekanan dan tantangan 
hidup agar dapat mencapai pribadi sehat sekaligus mampu menyesuaikan diri dengan baik di lingkungan baru manapun.

Seseorang yang memiliki penyesuaian diri yang efektif, mampu untuk mencapai tingkat keakraban yang cocok dalam membina hubungan sosialnya. Mereka biasanya mampu dan selalu merasa nyaman ketika berinteraksi dengan orang lain sekaligus mampu mengelola serta membangun hubungan dengan orang lain. Selain itu, mereka pun akan menjadikan orang-orang di sekitarnya nyaman dengan keakraban tersebut.

Berdasarkan studi pendahuluan yang dilakukan pada mahasiswa baru angkatan 2012 program studi Psikologi Universitas Negeri Jakarta, dengan penyebaran angket dan wawancara sederhana dengan pertanyaan seputar tentang permasalahan umum sebagai mahasiswa baru, deteksi awal yang didapatkan adalah mahasiswa baru mengalami kesulitan dalam penyesuaian diri.

Melihat adanya ciri-ciri yang menunjukkan adanya kesulitan dalam penyesuaian diri, peneliti ingin menggali lebih dalam mengenai gambaran sekaligus mencari tahu faktor-faktor apa saja yang mempengaruhi penyesuaian diri pada mahasiswa baru angkatan 2012 di program studi Psikologi UNJ.

Masalah yang akan diteliti muncul dalam bentuk pertanyaan penelitian: "Bagaimanakah gambaran dan faktor-faktor apa saja yang mempengaruhi penyesuaian diri mahasiswa baru angkatan 2012 program studi Psikologi UNJ?", maka penelitian ini bertujuan untuk memberikan gambaran dan mencari faktor-faktor yang mempengaruhi penyesuaian diri mahasiswa baru angkatan 2012 baru program studi Psikologi Universitas Negeri Jakarta.

\section{Metode Penelitian}

Metode penelitian yang digunakan adalah penelitian deskriptif dengan metode campuran sekuensial/bertahap (sequential mixed methods). Metode Ini melakukan prosedur-prosedur yang berusaha peneliti gabungkan atau dengan maksud memperluas penemuan-penemuannya yang diperoleh dari satu metode dengan penemuanpenemuannya dari metode yang lain. Penelitian ini dapat dimulai dari metode kuantitaitf terlebih dahulu dengan menguji suatu teori atau konsep tertentu, kemudian diikuti dengan metode kualitatif dengan mengeksplorasi sejumlah kasus dan individu (Creswell, 2011).

Pelaksanaannya berlangsung bertahap dimulai dengan metode survei (kuantitatif) dan wawancara (kualitatif). Metode campuran sekuensial ini dipilih karena penelitian ini bertujuan untuk memperoleh pemahaman yang lebih baik dari pendekatan yang berbeda terhadap fakta mengenai penyesuaian diri mahasiswa baru angkatan 2012 secara lengkap dan mendalam.

Sampel kuantitatif yang digunakan dalam penelitian ini sebanyak 51 orang responden dengan menggunakan teknik sampling insidental sampling yang secara kebetulan atau siapa saja yang secara kebetulan bertemu dengan peneliti dapat digunakan sebagai sampel bila dipandang orang yang kebetulan ditemui cocok sebagai sumber data (Sugiyono, 2008). Penelitian pada tahap kuantitatif ini menggunakan skala likert dan mengembangkan dimensi penyesuaian diri berdasarkan teori Haber dan Runyon 1984.

Karakteristik subjek pada tahap penelitian kualitatif ini adalah mahasiswa baru angkatan 2012 program studi Psikologi UNJ melalui hasil skor penelitian kuantitatif yang telah dilakukan sebelumnya. Pengambilan data kualitatif akan dilakukan pada tiga orang mahasiswa baru angkatan 2012, dengan melihat perbedaan dari hasil studi pendahuluan yang diketahui bahwa subjek tersebut memiliki berbagai permasalahan terkait dengan penyesuaian diri namun memiliki skor penyesuain diri yang termasuk dalam kategori tinggi pada hasil penelitian kuantitatif melalui instrumen final yang telah diberikan. Hal ini diharapkan akan mengungkap bagaimana proses penyesuaian diri dapat dengan singkat meningkat. Sekaligus mengetahui faktor-faktor apa yang mempengaruhi hal tersebut dengan menggunakan metode wawancara. Pemilihan significant person dari ketiga subjek berdasarkan teman terdekat subjek dalam perkuliahan, dengan alasan bahwa significant person dalam hal ini adalah teman dekat diharapkan dapat mengetahui keseharian subjek dalam perkuliahan yang banyak menghabiskan waktu bersama karena lingkup penelitian ini berfokus pada lingkungan perkuliahan. 


\section{Hasil Penelitian dan Diskusi}

Berdasarkan hasil perhitungan dengan menggunakan dimensi Haber dan Runyon, untuk kategorisasi skor penyesuaian diri secara keseluruhan dapat dinyatakan bahwa mahasiswa baru yang memiliki skor dengan kategori tinggi berjumlah 49 orang responden dan mahasiswa baru yang memiliki skor dengan kategori rendah berjumlah 2 orang.

Haber dan Runyon (1984) mengatakan bahwa ada beberapa karakteristik penyesuaian diri yang baik yang harus dimiliki seseorang yaitu, memiliki persepsi yang akurat terhadap realitas, mampu mengatasi kecemasan dan stres, memiliki citra diri yang positif, mampu mengekspresikan perasaan dan memiliki hubungan interpersonal yang baik (Haber dan Runyon, 1984). Maka jika melalui penjelasan diatas, persentase responden penelitian penyesuaian diri yang diukur berdasarkan dimensi penyesuaian diri pada mahasiswa baru program studi Psikologi UNJ pada pembahasan sebelumnya termasuk dalam penyesuaian diri yang pada kategori yang tinggi.

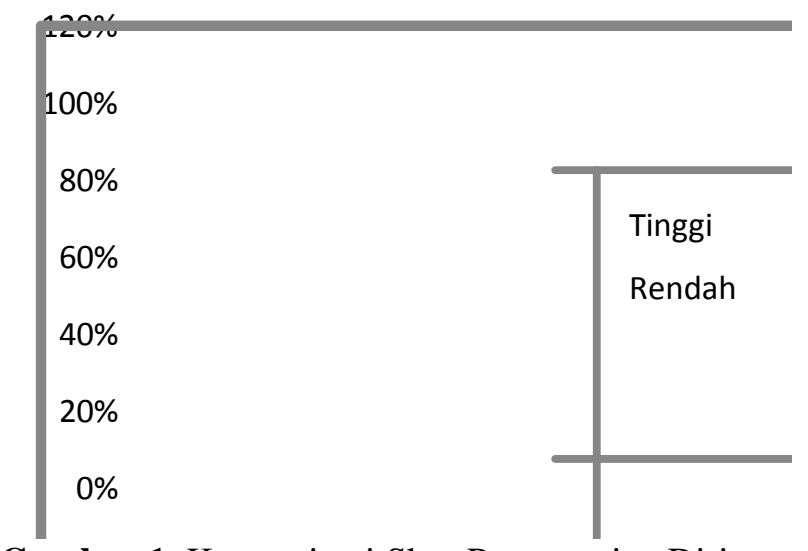

Gambar 1. Kategorisasi Skor Penyesuaian Diri

Berdasarkan hasil kualitatif, diketahui bahwa faktor-faktor yang mempengaruhi penyesuaian diri pada mahasiswa baru angkatan 2012 program studi Psikologi UNJ adalah: 1) lingkungan teman sebaya yang merupakan faktor penting dalam penyesuaian diri pada masa remaja. Teman-teman yang saling mendukung dan merasa mengalami sebuah perjalanan pengalaman yang bersama, 2) proses belajar dalam perkuliahan, dalam proses belajar ini mahasiswa menjadi lebih memahami karakteristik dosen dan pembelajaran di setiap mata kuliah yang dipelajari 3) kemauan dalam belajar, merubah kebiasaan belajar saat masih berada di bangku sekolah dengan kebiasaan yang lebih menuntut tanggung jawab pribadi di perguruan tinggi, 4) kegiatan atau program di luar aktivitas akademik yang dilakukan oleh badan eksekutif dapat membantu mahasiswa baru agar lebih mengenal senior serta mendapat bimbingan dan ilmu di luar perkuliahan formal.

Menurut Schneider (Ali \& Asrori, 2011) setidaknya ada beberapa faktor yang dapat mempengaruhi proses penyesuaian diri remaja, salah satunya adalah faktor lingkungan, dalam hal ini adalah lingkungan fisik dan teman sebaya dalam perkuliahan. Faktor yang mempengaruhi proses penyesuaian diri selanjutnya menurut Schneider adalah proses belajar. Proses belajar termasuk faktor penting dalam proses belajar yang dapat mempengaruhi penyesuaian diri individu (Ali \& Asrori, 2011). Kemauan belajar merupakan unsur penting dalam penyesuaian diri karena umumnya respons-respons dan sifat-sifat kepribadian yang diperlukan bagi penyesuaian diperoleh dan menyerap ke dalam diri individu melalui proses belajar. Selain dua faktor-faktor yang mempengaruhi penyesuaian diri pada individu menurut Schneider di atas, faktor-faktor yang mempengaruhi ketiga subjek dalam menyesuaikan diri di lingkungan kampus adalah faktor kegiatan di luar aktivitas akademik. Dalam hal ini pihak eksekutif mahasiswa banyak mengadakan kegiatan dan program bagi mahasiswa baru agar lebih mengenalkan dunia perkuliahan dalam bidang akademik maupun keorganisasian seperti Masa Pengenalan 
Akademik (MPA), Pelatihan Kepemimpinan Mahasiswa Jurusan (PKMJ) dan kegiatan kampus lainnya.

\section{Kesimpulan}

Hasil penelitian ini memiliki kesimpulan bahwa penyesuaian diri mahasiswa baru angkatan 2012 program studi Psikologi Universitas Negeri Jakarta termasuk dalam kategori tinggi.

Berikut adalah beberapa aspek yang diketahui sebagai faktor-faktor yang mempengaruhi penyesuaian diri pada mahasiswa baru angkatan 2012 program studi Psikologi UNJ: 1) lingkungan teman sebaya, 2) proses belajar dalam perkuliahan, 3) kemauan dalam belajar, 4) kegiatan atau program di luar aktivitas akademik yang dilakukan oleh badan eksekutif.

Setiap penelitian yang dilakukan selalu berharap memberikan kontribusi dan pengaruh bagi banyak aspek kehidupan, begitu juga dengan penelitian ini dengan judul gambaran penyesuaian diri pada mahasiswa baru. Penelitian ini diharapkan dapat memberikan implikasi pada subjek itu sendiri, para mahasiswa baru yang akan datang, seluruh civitas akademika dan lembaga yang bersangkutan agar dapat mengetahui gambaran penyesuaian diri pada mahasiswa baru yang masih harus menyesuaikan diri dengan kebiasaan, kemandirian tuntutan perkuliahan, dimana mereka masih terbiasa dengan kondisi yang teratur di sekolah dan masih baru awam dalam pengetahuan dasar tentang dunia perkuliahan serta dengan mengetahui faktor yang membantu dalam penyesuaian diri akan memudahkan seseorang dalam menyesuaikan diri di lingkungan baru. Penyesuaian diri penting dilakukan oleh setiap pribadi yang sedang menghadapi lingkungan atau sebuah kondisi yang baru.

\section{Daftar Pustaka}

Aetama. (2012). Pengertian Mahasiswa. diakses pada tanggal 3 Oktober, 2012. From http://id.shvoong.com/socialsciences/education.

Ali, M \& Asrori. (2011). Psikologi Remaja, Perkembangan Peserta Didik. Jakarta: PT. Bumi Aksara.

Haber, R.P. \& Runyon. (1984). Psychology of Adjusment. America: The Dorsey Press.

Hurlock, E. (1999). Psikologi Perkembangan: Suatu Pendekatan Sepanjang Rentang Kehidupan. Edisi Kelima. Jakarta: Penerbit Erlangga.

Santrock. (2002). Life Span Development; Perkembangan Masa Hidup, terj. Jilid II. Jakarta: Penerbit Erlangga.

Spencer, S \& Jeffrey. (1992). Adjusment and Growth: The Challenge of Life. Philadelphia: Holt, Rinehart and Winston, Inc.

Sugiyono. (2008). Metode Penelitian Pendidikan, Pendekatan Kuantitatif, Kualitatif dan $R \& D$. Bandung: Penerbit Alfabeta.

Wikipedia. Pengertian Mahasiswa. Diakses pada tanggal 10 Oktober, 2012. From www.wikipedia.com 